\title{
A CYBORG-ANIMAL IMAGE IN B. VERBER'S WORK "HER MAJESTY THE CAT"
}

\section{Poltoratska Alla}

ORCID ID 0000-0002-6941-6907

Candidate of the Department of Slavic Philology, Comparativistics and Translation

Academic Institute of Philology, Translation and Journalism

Nezhinsky State University named after Nikolai Gogol

2, Grafskaya str, 16600, Nizhyn, Ukraine

apoltoratska@gmail.com

The article focuses on the novels «Tomorrow The Cats» (2016) and «Her Majesty the Cat» (2019) by French author B. Werber, in which the author presents one of his options for the future interaction of a man with an animal, where the latter is depicted outside the traditional perception of a man. The work explores the writer's vision of future relationships between species and the conditional symbiosis of animals and people in order to save both. The study examines cyborg-animals that strive to change the world order.

The writer in the novels presents a new level of human interaction with another (laboratory animal, cyborg animal) and calls for revision of the generally accepted human perception of animals. A man must abandon traditional highness and consider ways to stop environmental problems, among which are the extinction of rare species of animals.

The author tries to warn a person, therefore describes a number of situations in which a man appears to be cruel to the world around, and to protect a future man from results of her own actions. Against the background of the war, the author depicts the problem of human interaction with the outside world, in which the threat to everything alive is not only looting, plague, but also the invasion of rats who seek to dominate the city. For general salvation, animals unite with people, which makes it possible for the writer to interpret the image of an animal as a species close to humans. B. Werber says that the mission of people on earth is changing, they should worry not only about their species, but also about the world around and notes "The Earth is laid to the same extent to all forms of life, animals or plants that inhabit it. And no species objectively has the right to proclaim itself "higher than others"».

Keywords: animal, man, Bernard Werber, cyborg, life.

\section{ОБРАЗ ТВАРИНИ-КІБОРГА У ТВОРІ Б. ВЕРБЕРА «ї̈̈ ВЕЛИЧНІСТЬ КІШКА»}

\section{Полторацька Алла}

ORCID ID 0000-0002-6941-6907

пошукувачка кафедри слов'янської філології, компаративістики та перекладу

Навчально-науковий інститут філології, перекладу та журналістики

Ніжинського державного університету імені Миколи Гоголя

вул. Графська, 2, 16600, м. Ніжин, Україна

apoltoratska@gmail.com

У иентті уваги статті - романи «Завтра будуть коти» (2016) та «їі величність кішка» (2019) франиузкого автора Б. Вербера, в якому автор репрезентує один з варіантів майбутньої взаємодії людини з твариною, де остання зображена за межами традииійного сприйняття людини. У роботі проаналізовано бачення письменником майбутніх взаємозв'язків між видами та умовний симбіоз тварин $i$

(C) Poltoratska A., 2020 
людей заради порятунку кожного. У дослідженні розглянуто тварин-кіборгів, які прагнуть змінити світовий лад.

Письменник у романах репрезентує новий рівень взаємодї людини з Іншим (лабораторною твариною, твариною-кіборгом) $i$ закликає до перегляду узвичаєного людського сприйняття тварин. Людина має відмовитися від традиційної вищцості $i$ обміркувати шляхи зупинення екологічних проблем, серед яких є вимирання рідкісних видів тварин.

Автор прагне застерегти людину, тому описує ряд ситуаиій, в яких людина постає жорстокою до світу навколо та вберегти людину майбутнього від результатів ї̈ ж власних дій. На фоні війни автор зображує проблему взаємодії людини з навколишнім світом, в якому загрозою всьому живому $\epsilon$ не лише мародерства, чума, а і пошесть щурів, щзо прагнуть домінувати над містом. Для загального порятунку тварини об'єднуються з людьми, щчо дає можливість письменнику інтерпретувати образ тварини як вид близький людині. Б. Вербер говорить про те, шзо місія людей на землі змінюється, вони мають турбуватися не лише про свій вид, але і про світ навколо $і$ зазначає «Земля належить однаковою мірою всім формам життя, тваринним чи рослинним, які ї̈ населяють. I жоден вид об'єктивно не має права проголошувати себе “вищим, ніж інші"》.

Ключові слова. тварина, людина, Бернар Вербер, кіборг, життя.

Вступ

Кінець XX - початок XXI століття характеризується дестабілізацією, кризами, втратою межі між людиною і твариною, увагою до біологічного, кризою ідентифікації людини, децентралізацією «Я», коли «людина усвідомлює буття в межових ситуаціях, ситуаціях вибору та конфлікту» (Доманська, 2012, 84). Ці проблеми проявляються і в сучасному зв'язку людини з не-людиною. Людина вибудовує «новий» стан свого буття поряд 3 іншими істотами. Письменники відчули цю проблему і прагнуть знайти ії вирішення у творах. Такі трансформації вплинули на проблематику сучасної художньої літератури, на етичну площину зв'язку людини 3 твариною, на місце нелюдей у людському світі, на зміну їхнього безправного становища та на формування нової тенденції у розумінні тварини, в якій людина починає відчувати не-людину та її потреби. Ці варіації спостерігаються як у зміні образу головного персонажа (приміром, роман «Безчестя» Дж. Кутзее), так і в розуміння людиною рівності 3 твариною (приміром, роман «Вуличний кіт на ім'я Боб» Дж. Бовена). Людина поділяє цей світ 3 іншими живими істотами, тому має турбуватися про навколишній світ, в іншому разі природа може сама «обрати» покарання для людини 3 грабіжницькою та споживацькою філософією розуміння світу (приміром, роман «Веди свій плуг понад кістками мертвих» О. Токарчук). Нові тенденції у художній літературі дають змогу зрозуміти, що панування неможливе над жодною з істот Планети.

\section{Матеріали та методи дослідження}

Матеріалом цього дослідженням є другий роман з трилогії про котів Б. Вербера («Завтра будуть коти», «її величність кішка», «Планета котів»), в якій автор окреслює один із варіантів майбутньої взаємодії людини з твариною. У книзі образи людей і тварин рівноправні, проте людина постає еволюційно досконалішою (будова тіла: вміння ходити, наявність пальців; тривалість життя), хоча коти теж мають свої переваги над видом людини (вміють тримати рівновагу, бачити вночі).

Мета дослідження: прослідкувати динаміку образів не-людини (на матеріалі роману Б. Вербера «Ії величність кішка»).

Завдання дослідження: охарактеризувати образи тварин-кіборгів та встановити умови гармонійного симбіозу людини з не-людиною.

Із огляду на мету і завдання в праці використано такі методи: екоцентричний, який дав змогу осмислити взаємодію людини й природи 3 антропозооцентричного погляду; методик сучасної наратології для вивчення оповідної структури романів 
Б. Вербера; комплексного аналізу художнього тексту, необхідного для дослідження специфіки сюжетів творів; порівняльний аналіз критичних праць для окреслення основних тенденцій специфіки творчості Б. Вербера; герменевтичний аналіз художнього тексту для осмислення змістової єдності художнього твору та його розуміння. Крім того застосовано елементи рецептивного й описового методів.

\section{Обговорення}

У XXI столітті амплітуда віддалення культури від класичних гуманістичних цінностей зростає, тому «нові» форми гуманізму розглядаються як симптоми і початки процесу дегуманізації. У зв’язку 3 цим Є. Доманська зауважує, що упродовж останнього десятиріччя гуманітаристика та соціальні науки переживають істотні зміни, які пов'язані з кризою гуманістичної ідеології, негуманності людини у ставленні до тварини та зникненням межі між людиною і не-людиною. Р. Маламуд стверджує: «Тварини, яких ми уявляємо 3 нашого боку кордону, в основному $є$ конструкціями божевільними собаками, німими зайчиками, зайнятими бджолами, скаженими биками, - які обслуговують безліч культурних та образних потреб» (R.Malamud, 2003) людей. Люди антропоморфізують їх і за рахунок цього відчувають свою владу над не-людьми. Конфлікт гуманістичних принципів та ідеалів 3 реальністю спричинює переформатування гуманізму, формування нової концепції людини та її взаємодії з нелюдьми. Соціокультурною формою вираження кризи гуманізму є постгуманізм, як дискурс чи як комбінація матеріальних, символічних i політичних змін, що відбуваються в рамках традиційних знань та інформаційної політики. У політичному сенсі постгуманізм пропонує об'єднання тих галузей, що були відокремлені міждисциплінарними кордонами. Серед дослідників у царині постгуманізму слід назвати: Н. Бадмінтона (Бадмінтон, 2000), Р. Брайдотті (Брайдотті, 2013), Н. Висоцької (Висоцька, 2013), К. Вулфа (Вулф, 2009), Д. Геревей (Геревей, 1991), К. Гейлз (Гейлз, 2008), Є. Доманської (Доманська, 2012), Ф.Фукуяму (Фукуяма, 2002), М. Шимчишин (Шимчишин, 2013), Ф. Феррандо (Феррандо, 2013) та інші. У центрі уваги теоретиків постгуманізму, на думку М.Шимчишин, є «багатоманітність форм життя, колапс онтологічних кордонів та взаємодія між людьми, тваринами та машинами, соціополітичні наслідки подальшого впровадження технологій та біотехнологій» (Шимчишин, 2013: 486).

Постгуманізм експериментує 3 новим, досліджує стосунки між не-людьми, рослинами, предметами та тим, що вважається людиною. Постгуманістична філософія розкривається через розуміння того, що означає сьогодні бути людиною (постлюдством), iї представники закликають до переосмислення відносин із тваринами в епоху розвитку технологій. Д. Геревей у праці «Маніфест кіборга» доводить, що технофілія жодним чином не заперечує органофілії. Хоча і відбувається руйнування непроникних кордонів в обох режимах - «людина-машина» і «людина-тварина» (Д. Геревей, 1991), що сприяє подоланню прірви між цими традиційними позиціями. При цьому Д. Геревей наполягає на необхідності випрацювання дискурсу, що враховував би живу, повсякденну конкретику Іншого, замість його символізації та метафоризації, як це найчастіше відбувається в літературі. «Великі розколи між тваринним/людським, природою/культурою, органікою/технікою та диким/прирученим зводяться до повсякденних відмінностей - таких, що мають наслідки та потребують поваги і дії, радше, ніж піднесення до величних та остаточних цілей» (Геревей, 1991).

К. Гейлз у книзі «Як ми стали постлюдством» вказує, що постгуманізм відносно нова філософія, що, з одного боку, звертає увагу на онтологічні умови, що допомагають людині вдосконалитися технічно та мати можливість жити в тісному зв'язку з машинами чи іншими органічними формами; з іншого боку, пропонує нове трактування людини, разом 3 тим враховує попередній досвід, що переконує про домінування людини над іншими живими формами. Постгуманізм прагне прибрати традиційні межі та довести, що людина не виняткове створіння (Гейлз, 2008). 


\section{Результати дослідження}

Одним із сучасних авторів, хто піддає сумніву винятковість людини і їі панівну позицію є Б. Вербер, який народився 18 вересня 1961 року в місті Тулуза, Франція. Писати почав твори 3 раннього віку. За час навчання в університеті вивчав криміналістику, право, журналістику, полюбляв відвідувати зали суду, бути присяжним.

У 1983 році отримав премію за репортаж про мурах. Через 8 років вийшла перша книга $з$ трилогії про цих тварин, яка і принесла йому популярність. Серед вподобань автора: езотерика, фантастика, філософія, психологія, вивчення світу тварин, що і лягли в основу всіх його творів.

У контексті нашого дослідження вартим уваги роман «їі величність кішка» (2019) з трилогії про котів Б. Вербера, в яких автор показує власне розуміння одного 3 можливих варіантів зв'язку людини з твариною в майбутньому.

Бастет і Піфагор - головні персонажі трилогії Б. Вербера. Нарація ведеться від кішки Бастет. Письменник репрезентує Бастет як «трирічну довгошерсту кішку, білу 3 чорними латками, розташованими надзвичайно гармонійно, особливо та що на мордочці, у формі перевернутого серця» (Вербер, 2020: 7), згадує про іï недоліки та переваги. Головна їі відмінність від решти істот - любов до себе, на відміну від інших істот, які, на її погляд, «ненавидять себе» (Вербер, 2020: 8). Ім'я пов’язане з богинею Бастет - «божеством єгипетського міста Бубастіс» (Вербер, 2020: 248). Традиційно іiі зображували у двох подобах: подобі «жінки з головою кішки та звичайної кішки». Далі письменник інформує: «Була богинею музики, сексуальної насолоди і плодючості. <...> переважно Бастет зображали доброю й прихильною, та якщо не вшанувати їі, то лютого гніву не уникнути» (Вербер, 2020: 248-249). Фактично всі окреслені риси проявляються і в образі кішки у трилогії Б. Вербера. Їй подобається музика, вона добра стосовно тварин і людей, але до того часу, поки ії не образили чи не принизили. Бастет вважає: «Ніхто не має права так мене принижувати. Особливо люди, єдиним покликанням яких є служіння мені» (Вербер, 2018: 42), тому вона думає, що всі люди потворні, бо «хочуть знищити те, що подібне до них» (Вербер, 2018, 46) і не мстить їм, бо «найгірші вороги людей...самі люди» (Вербер, 2020: 11).

Головне завданням Бастет - «привести до порозуміння між собою всі біологічні види» (Вербер, 2020: 9). Кішка відрізняється від інших тварин, серед яких вона знаходиться. Приміром, разом з нею мешкає кіт Фелікс, білий ангоровий кіт з жовтими очима, який після кастрування «набрав вагу та споглядав свої втрачені атрибути над екраном телевізора 3 перервами на футбольні матчі» (Вербер, 2020: 9). Ця тварина прагне спокійного життя, яке не сповнене пригод та боротьби.

Бастет протягом всього твору говорить про поведінку людей, які в межових ситуаціях не можуть спокійно мислити. Їхнє становище непросте: йде епідемія чуми, збільшується кількість пацюків, люди слабшають, чума поширюється - це призводить до посилення віддаленості людей одне від одного і до нестабільності світу. Бастет відзначає «занепад людської цивілізації». На погляд кішки, причиною цієї кризи постали самі люди, які «замість того, щоб боротися за життя, <...> боролися за смерть. Вони вибирали вбивство собі подібних через те, що вони не такі, замість спроби порозумітися задля спільного виживання. Вони перетворилися на звірів» (Вербер, 2020: 12). Люди прагнуть вижити за будь-яку ціну, тому не витрачають час на роздуми стосовно власних дій. Бастет, після пояснення Піфагора, замислюється на поведінкою людини, що жорстока як до тварин (приміром, знищення кошенят Бастет), так і до власного виду (теракт у дитячому садку, напад на самотню людину).

Чума постає межовою ситуацією, певним індикатором світу, у якому кожен вид самостійно обирає як йому жити: чи розвиватися, чи стояти на місці. У творі людство зображено двопланово: 3 одного боку - люди, які не зупиняються на досягнутому, розвиваються, вбачають у тварині істоту, яка теж має права, а з іншого - люди, які не прагнуть змін, які хочуть жити у світі кордонів, лише для того, щоб задовольняти свої 
потреби, через що часто стають агресивними та жорстокими стосовно інших видів. Б. Вербер на фоні війни зображує проблему взаємодії людини зі світом навколо, в якому загрозою всьому живому $є$ не лише мародерства, чума, пошесть щурів, що прагнуть домінувати над містом, але і сама людина.

У першій частині трилогії Бастет встановлює контакт із людською шаманкою Патрисією і їм вдається об’єднатися 3 людьми. Єдиним порятунком живих істот (480 котів та 180 людей) стає острів Сіте, як біосимбіотичний сховок від нападу щурів. На перший погляд це місце безпечне, i, навіть, коти тут зможуть «спокійно готуватися до періоду «постлюдства» (Вербер, 2020: 36), яке до певного часу було «вищим за всіх та не зуміло втриматися» (Вербер, 2020: 284) на своїх позиціях. 3 часом Бастет і Піфагор розуміють, що залишатися на острові небезпечно, пацюки беруть їх в облогу, тому потрібно діяти. Вони разом з Наталі, «служницею» Бастет, прагнуть знайти шлях до порятунку всього їхнього союзу. Тепер людина з тваринами має одну мету врятуватися,. Бастет переконана: «Мир - це єдиний правильний шлях» (Вербер, 2020: 51) і тому вони мають досягти його.

У романах «Завтра будуть коти» та «Ії величність кішка» Бастет не лише мислить, аналізує, прогнозує, але і не зупиняється на досягнутому. У другій частині трилогії вона не просто хоче навчитися читати, писати, але й написати твір для котів і людей. Крім цього кішка мріє про створення майбутньої котячої цивілізації, яка може змінити людську. Традиційне розуміння тварин теж присутнє у творі. Бастет переконана, що люди ніколи не вважатимуть вид котів рівними із собою істотами, адже людям важко відмовитися від панівних позицій і звернути увагу на не-людей, які поряд, і подивитися на них не на як підкорених, а як на рівних.

Цікавий у романі образ Піфагора, сіамця, лабораторного кота, в черепі якого розміщений механізм з USB-портом, що дає йому змогу користуватися Інтернет павутиною, розвиватися та розуміти світ довкола. Завдяки цим можливостям, Піфагор стає рівним людині. Він вміло користується інформацією i, навіть, налагоджує двосторонній зв'язок з людиною. Фактично, він постає «єдиним мостом між цивілізаціями» (Вербер, 2020: 31). Піфагор з Наталі створили програму, яка дає змогу людям розуміти мову котів i навпаки. Він також прагне створити повноцінну Енциклопедію Відносного та Абсолютного знання, в якій буде інформація, що дасть змогу людині зрозуміти вид котів і підштовхнути людей до самоаналізу власних дій щодо не-людей (тварина описує взаємодію людей i тварин за часів неоліту, середньовіччя, сучасності; наводить відмінні риси між людьми i тваринами; виокремлює розумних тварин і т. д.). Піфагор постає твариною, яка не піддається інстинктам, а яка вміє віднайти баланс між власними знаннями та власними діями. Через образ Піфагора автор прагне показати шлях до правильного застосування знань, які не завдадуть шкоди людському виду, а навпаки, допоможуть порозумітися з усім біорізноманіттям живих істот, тобто це мудрий і далекоглядний кіт-кіборг.

Піфагор відрізняється від решти «технологізованих» тварин тим, що незважаючи на життя в лабораторії, участь у експериментах та непростих умовах буття, він не втрачає себе. Кіт стає вище над почуттями агресії та жорстокості як щодо тварин, так і до людей. Піфагор вдало балансує у світі інформації і бере лише найкращі риси людей, вчиться самостійно мислити, аналізувати, прогнозувати, вдосконалюватися - усе це його вибір. Показове в цьому плані й ім'я - Піфагор: ім'я видатного мислителя доби Античності, який «прославився своєю теоремою <..> Він придумав слова "філософія" та "математика". І саме він створив першу музичну гаму» (Вербер, 2020: 82). Тварина у романі змальована в ролі мудреця, якого захищає і оберігає Бастет.

Піфагор знає всю історію взаємовідносин людей і тварин. Володіючи цією інформацією, він все одно не бажає помсти, а навпаки, хоче навчити людину бути людиною, бо людство «таке парадоксальне, в людей найсвітліший розум іде пліч-опліч із глибокою дурістю» (Вербер, 2020: 158). Для убезпечення людей, він створює Енциклопедію, в якій описані дії людей щодо тварин. Він ніби розширює людський 
РЕВАЗ і доповнює його 3 не-людського погляду, щоб людина розгледіла втрату світової рівноваги через власну байдужість.

Кіт Піфагор - «сучасна» не-людина, кіт вищого рівня, який самостійно усвідомлює той факт, що людина сильніша за фізіологічними можливостями, але слабша через використання своїх знань Тварина прагне донести людині очевидне: інформація про світ відома людині, проте вона не використовує іiі 3 користю, а скеровує на саморуйнацію: «...іноді складається враження, що люди використовують свої здібності проти себе» (Вербер, 2020 158-159), на збільшення агресивності, що перешкоджає людині вийти за межі інстинктивного життя. Людське життя перестало бути цінністю, як це було спочатку з життям тварини - це один із сигналів сьогодення про невірний спосіб розуміння людиною дійсності. Тварина постає мудрою, цю мудрість «вклала» в Піфагора Софі - вчена, яка опікувалася ним спочатку в лабораторії, а потім вдома.

Відмінність Бастет і Піфагора полягає в тому, що Третє Око (USB-порт) вона отримує не після низки дослідів, не в лабораторії, не примусово, а добровільно. Піфагор підготував її до нової інформації, а Наталі пояснила людський спосіб розуміння світу: через любов, гумор і мистецтво.

Кішка займає проміжне місце між Піфагором і Тамерланом (ватажком щурів). Бастет не бажає людям зла, проте мріє на місці людського суспільства створити «державу» котів, де вона постане у статусі «ї̈ ВЕЛИЧНІСТЬ КІШКА» (Вербер, 2020: 184). Бастет не зупиняється на малих перемогах чи поразках, тому весь час рухається вперед у своїх знаннях. У цьому їй допомагає Піфагор.

Хронотоп твору змінний, спочатку персонажі подорожують Парижем. На долю «мандрівників» (людей і тварин) випадає низка випробувань. Одне 3 яких подорож до університету в Орсе, де Піфагор показує Бастет віварій - місце, де проводилися досліди над ним та іншими тваринами; тут він був першим котом, якому провели операцію вживлення в мозок USB-порту, серед піддослідних були й інші тварини: мавпи, пацюки, кролі, свині, i, навіть, один кінь. 3 часом ці тварини стали агресивними, деяким вдалося втекти. За час їхніх пригод Бастет теж вдається стати котом-кіборгом. Тепер вона відчуває не лише співчуття до іншого виду, але і має змогу, за допомогою винаходу Піфагора, розмовляти 3 людиною. За допомогою людини тварина еволюціонує i у складних життєвих ситуаціях вони постають рівними, i, навіть однаково беззахисними. Бастет переконана, що для того, щоб «нові покоління жили у світі без війни, потрібне колективне обговорення за участі всіх видів. <..> людей, котів, собак, свиней, корів, вовків, овець, птахів, риб, жуків, <..> навіть рослин» (Вербер, 2020: 256). Наприкінці другої частини спільнота людей і тварин вирушає 3 Франції до Америки.

Зміни у творі прослідковуються не лише на рівні розуміння взаємозв'язку людини 3 твариною, але і на рівні зміни традиційної репрезентації образів тварин, приміром, собаки призвичаїлися до життя і більше не потребують людської опіки. Вони самостійні. Свині мають людські імена і бажають помститися людям за жахливі умови їхнього життя: «Наші голови тримали між гратами, а наші рила постійно були занурені в корм. <..> Уявіть собі життя, позбавлене руху, єдиною метою в якому є набрати вагу та піти на м'ясо, чим жирніше й соковитіше, тим краще. Сдина ціль людей - якнайбільший прибуток» (Вербер, 2020: 177). Вербер звертає увагу читачів на проблеми сьогодення. Нині існує значна кількість досліджень, літератури, фільмів та відеороликів, що детально репрезентують умови життя тварин. Проте для масштабного виробництва в пріоритеті є дохід, а решта - не має значення. Наприклад, відлучення «поросят від свиноматки через десять днів після народження призведе до депресії та довічної тяги до смоктання та жування <...> Це спричинить до хвороб у майбутньому. Оскільки лікування хворих тварин не є економічно вигідним, то їх чекає смерть» (Polland, 2006). Життя та умови вирощування тварин є другорядними i, навіть, нецікавими людині, головне - збагачення. Поряд 3 цими словами, існує й інакша думка: хоча люди і завдають страждань тваринам, але «завдяки їм вони і існують» 
(Вербер, 2020: 182). Автор прагне змусити людину замислитися над своїми вчинками i допомогти людині все ж стати гуманною стосовно не-людей, тому і пише про це.

Один із головних мотивів другої частини - думка про те, що людська раса деградує, у зв'язку з цим світ постав перед загрозою щурів. Лідер пацюків Тамерлан щур, на якому люди ставили досліди та навчили виживати і адаптуватися до різних умов. Він ненавидів їх і прагнув помститися за все зло, яке вони йому завдали. Невипадкове ім'я тварини - Тамерлан, який запам'ятався в історії «найжорстокішим та найкривавішим 3 усіх середньовічних завойовників. Про нього згадують як про «катастрофу в історії», бо він провів своє життя у війнах не з метою створення імперії, а просто тому, що отримував задоволення від масового винищення людей у жорстокий спосіб, зі знущаннями і тортурами» (Вербер, 2020: 40). Такий же Тамерлан у трилогії: безжалісний, готовий на все заради помсти; не дотримується слова, не бажає миру, прагне смерті іншим істотам. Щур скеровує своє військо на острів Сіте: «На двох припасованих у формі літери Т дровинах - розіп'ятий лев Ганнібал < ..> Бідолаху геть понівечили - повидирали навіть зуби й кігті. Таке собі послання від щурів: мовляв, ми можемо знищити навіть найкращого вашого воїна» (Вербер, 2020: 204). Пацюки настільки швидко адаптуються до умов життя, що 3 легкістю вчаться отримувати вогонь, катувати та навіювати страх на інших істот.

Тамерлан теж тварина-кіборг, має Третє Око. Під його керівництвом відбувається напад на сховок людей і тварин на остові Сіте, після якого вціліло лише 193 коти та 16 людей. Тамерлан має зовсім інший погляд на людей, ніж Бастет та Піфагор. Він вважає: «люди так пишаються своїми знаннями й технологіями, що їм аж кортить похизуватися своєю вищістю перед іншими видами» (Вербер, 2020: 235). Щур бажає відібрати у них предмет хизування - РЕВАЗ (розширена енциклопедія Відносного та Абсолютного Знання), щоб за умови втрати пам'яті, людство не мало змоги відновитися. Зберігати цей носій доручають кішці, який вона носить на шиї.

Бастет зустрічається з Тамерланом, щур розповідає тварині про себе, відносини 3 людьми та про причину ненависті до них. Пацюк змальований як антигерой, який своєю поведінкою має вплинути на людину. Тамерлан оповідає Бастет історію свого життя: жив в лабораторії, на ньому випробовували ліки, тримали під водою, був свідком катувань інших звірів: «дослідження тривали, а щурів і далі катували, топили, після чого стинали голови. Сотні мертвих тварин кидали просто у смітник чи передавали у відділ рептилій - на корм зміям» (Вербер, 2020: 233). Щур весь час очікував, щоб помстися людям. На його думку, «лють рятує від відчаю» (Вербер, 2020: 234), тому він прикидався милим створінням, яке «схиляється перед всемогутніми людьми» (Вербер, 2020: 234), які хотіли перевірити, хто буде розумнішим: він чи Піфагор. Тамерлан нападає на Бастет, але їй вдається втекти і врятувати РЕВАЗ. Таким чином, боротьба між видами (людьми, котами та щурами) передає ще одну проблему людської недалекоглядності, адже людина, надаючи доступ не-людям до готових знань, не відає до кінця наслідків цього доступу, не розуміє майбутніх масштабів такої «довіри» (чи буде благо, чи навпаки - зловживання цими знаннями).

Бажання пацюків протистояти світу людей вказує на кризову ситуацію сучасного життя, адже нижчий рівень, пацюки, відповідно до традиційної градації, протистоять вищому рівню - людині. Невипадково автор обирає цього персонажа, адже «їхня агресивність, вражаюча адаптивність та плодючістю дають їм перевагу над більшістю інших видів. Вже не кажучи про їнні «довгі різці, що здатні перегризти дерево» (Вербер, 2020: 12).

Як бачимо, тварини з USB-портом весь час змінюються, рухаються вперед, що сигналізує людям про необхідність нового етапу чи, навіть, устрою, який би враховував всіх істот різного походження. Тобто це істоти епохи постгуманізму. Тварин технологізують, а це дає можливість Б. Верберу вказати людям на важливості переосмислення усталених привілеїв, що традиційно існували у світі та на заперечення пріоритетності ієрархічних відносин (людини над твариною). Фактично кіборг 
(Тамерлан) постає «порятунком» у теперішньому «світі хаосу», керує природнім відбором та вирішує, яким людям дозволено жити на Землі, а кого потрібно знищити.

Кіборги у романі описані у двох аспектах: як інформація для роздумів і як спосіб прийняття інакшості (людей, тварин), з якою потрібно навчитися жити. Тварини стають тим дзеркалом, в якому людина бачить себе і прагне змінитися, а в ситуації апокаліпсису, вони постають рятівниками не лише людей, але й майбутнього планети. Кіборг виникає в той момент, коли вищість людини піддається сумніву і налагоджується зв'язок між людиною, твариною і машиною, де дві останні постають менш залежними від першої. Технологізація стає звичайним явищем сьогодення, а кіборгізація - один із способів життя в інформаційному світі.

У 2020 році вийшла остання книга трилогії Б. Вербера «Планета котів», в якій письменник описує взаємодію людей із тваринами у нетрадиційних умовах, що спровоковані непередбачуваністю життя у світі. Б. Вербер зауважує, що сьогодні ми перебуваємо на роздоріжжі, з якого можна вийти або на кращий шлях, або на гірший, «кішки - це не рішення, а лише спосіб показати, що ми можемо мислити інакше» (Smith, 2020).

Отже, про новий ракурс взаємодії людини з твариною сигналізує виникнення кіборгів, які своєю появою піддають сумніву панівну позицію людину. Вони не прописані до жодної з категорії, не з'явилися в результаті еволюції світу, а постають як штучно сформовані організми. Тварини-кіборги можуть отримувати дані завдяки USBпорту і мережі Інтернет, що дає можливість маніпулювати діями власного виду, стати ватажком, лідером (Бастет - котами, Тамерлан - щурами), мати беззаперечний авторитет. Звичайні тварини (без Третього Ока) сліпо йдуть за ними, бо переконані у правильності вчинків останніх, тому і не бажають їх аналізувати. Вони мають сильний характер, досягають мети будь-якою ціною.

\section{Висновки та перспективи}

Б. Вербер прагне застерегти людину, тому описує ряд ситуацій, в яких людина постає жорстокою як до світу навколо, так і до власного виду. Письменник бажає попередити людей про жахливі наслідки їхніх вчинків для того, щоб вберегти людину майбутнього від наслідків їі ж власних дій. Для цього Вербер репрезентує проблеми сьогодення: посилення людської жорстокості, небажання бути Людиною (свідомою), а просто жити без будь-яких цілей, закриваючи очі на посилення власної агресії.

Письменник описує новий рівень взаємодії людини 3 твариною: ставлення до тварини як до категорії Іншого (лабораторної тварини, домашнього улюбленця, тварини-кіборга). У романі тварина може розуміти мову, може читати, сприймати інформацію, прогнозувати, при цьому вона поводиться як людина, має мету і прагне товаришувати 3 людьми. Письменник фіксує трансформацію у взаємодії людини і тварини: Бастет вбачає у людині «слугу» (Наталі), яка може постати союзником у боротьбі з поневолювачами. Вона і Піфагор необмежені у своїх прагненнях. Вони рушійна сила, організатори протистояння пацюкам, які мають на меті знищення всього людського і не-людського. Б. Вербер говорить про те, що місія людей на Землі змінюється, вони мають турбуватися не лише про свій вид, але і про світ навколо, тому у романах автор репрезентує образи людини і тварини як рівноцінних партнерів, проте лише людина може окреслити правильний шлях, бо тварина, поки що, не досить досконала.

Таким чином, порятунок усього живого на Землі можливий за кількох умов: об’єднання всіх видів, які не прагнуть руйнації, які зможуть жити без традиційного панування, домінування та вищості. Б. Вербер засвідчує, що загроза людства сама людина, яка поширює свою агресію та жорстокість на інші види (щурів, свиней), що легко піддаються на ці почуття. Друга умова - відмова від позиції панування, адже «жоден вид тварин не має права володіти іншим видом. Земля належить однаковою мірою всім формам життя, тваринним чи рослинним, які іiї населяють. I жоден вид 
об'єктивно не має права проголошувати себе “вищим, ніж інші”, ні люди, ні коти» (Вербер, 2018, 176), усі вони важливі для збереження життя на планеті.

У межах отриманих результатів можна окреслити перспективу подальшого студіювання для вивчення людино-твариної взаємодії у останній книзі 3 трилогії Б. Вербера «Планета котів».

\section{СПИСОК ВИКОРИСТАНИХ ДЖЕРЕЛ}

Вербер, 2018 - Вербер Б. Завтра будуть коти. Переклад з франц Я. Тарасюк. Львів: Видавництво Terra Incognita. 2018. 216 с.

Вербер, 2020 - Вербер Б. Її величність кішка: роман [Текст] / Бернар Вербер; пер.з фр. Соломії Мартинович та Марії Абрамової. Львів: Видавництво Теrra Incognita, 2020. $296 \mathrm{c}$.

Висоцька, 2013 - Висоцька Н. Пиродокультура Донни Геревей: утопія міжвидової гармонії/ Н. Висоцька. Сучасні літературознавчі студії. 2013. Вип. 10. С. 95-109.

Доманська, 2012 - Доманська E. Історія та сучасна гуманітаристика: дослідження 3 теорії знання про минуле. Переклад з польської та англійської В. Склокін. Київ: Ніка-Центр. 2012

Полторацька, 2020 - Полторацька А. Образи тварин і людей у романі Бернара Вербера «Завтра будуть коти». Вісник Маріупольського державного університету. Серія: Філологія, 23. 2020

Шимчишин, 2013 - Шимчишин $M$. Парадигми та виміри постгуманізму / М. Шимчишин. Сучасні літературознавчі студії. 2013. Вип. 10. С. 484-492. Режим доступу: http://nbuv.gov.ua/UJRN/S1s_2013_10_47

Agamben, 2004 - Agamben G. The Open: Man and Animal. Translated by K. Attell. Stanford: Stanford University Press. 2004.

Badmington, 2000 - Badmington N. Posthumanism. Palgrave, 2000. 172 p.

Braidotti, 2013 - Braidotti R. The Posthuman. - Cambridge, UK: Polity Press, 2013; 81

Ferrando, 2013 - Ferrando F. Posthumanism, Transhumanism, Antihumanism, Metahumanism, and New Materialisms: Differences and Relations. Existenz: An International Journal in Philosophy, Religion, Politics, and the Arts. 2013. Vol. 8. No. 2. P. 26-32.

Fukuyama, 2002 - Fukuyama F. Our Posthuman Future: Consequences of the Biotechnology Revolution. Farrar, Straus and Giteux / F. Fukuyama. New York: Oxford University Press, 2002.

Haraway, 1991 - Haraway D. A Manifesto for Cyborgs: Science, Technology, and SocialistFeminism in the Late Twentieth Century. Simians, Cyborgs, and Women: The Reinvention of Nature/ - N/Y/: Routledge, 1991.

Hassan, 1977 - Hassan I. Prometheus as Performer: Toward a Posthuman Culture? Performance in Postmodern Culture. The Georgia Review. 1977.: 830-850. Web.

Hayles, 2008 - Hayles K. How we become Posthuma: Virtual Bodies in Cybernetics, Literature, and Informatics. University of Chicago Press, 2008, 364 p.

Polland, 2006 -Polland M. The Omnivore's Dilemma: A Natural History of Four Meals New York: Penguin, 2006, 218 p.

Malamud, 2003 - Malamud R. Poetic Animals and Animal Souls. New York: Palgrave Macmillan, 2003.

Wolfe, 2009 - Wolfe C. What Is Posthumanism? U of Minnesota Press, 2009, 357 p.

\section{REFERENCES}

Werber, 2018 - Werber B. Zavtra budut koty. Pereklad z frants Ya. Tarasiuk. Lviv: Vydavnytstvo Terra Incognita. 2018. - 216 p. [in Ukrainian]

Werber, 2020 - Werber B. Yii velychnist kishka: roman [Tekst] / Bernar Verber; per.z fr. Solomii Martynovych ta Marii Abramovoi. Lviv: Vydavnytstvo Terra Incognita, 2020. - 296 p. [in Ukrainian] 
Vysotska, 2013 - Vysotska N. Pyrodokultura Donny Harawey: utopiia mizhvydovoi harmonii/ N. Vysotska. Suchasni literaturoznavchi studii. 2013. Vyp. 10. P. 95-109 [in Ukrainian]

Domanska, 2012 - Domanska E. Istoriia ta suchasna humanitarystyka: doslidzhennia z teorii znannia pro mynule. Pereklad z polskoi ta anhliiskoi V. Sklokin. Kyiv: Nika-Tsentr. 2012 [in Ukrainian]

Poltoratska, 2020 - Poltoratska A. Obrazy tvaryn i liudei u romani Bernara Verbera Zavtra budut koty. Visnyk Mariupolskoho derzhavnoho universytetu. Seriia: Filolohiia, 23. 2020 [in Ukrainian]

Shymchyshyn, 2013 - Shymchyshyn M. Paradyhmy ta vymiry posthumanizmu / M. Shymchyshyn. Suchasni literaturoznavchi studii. 2013. Vyp 10. P. 484-492. Retrieved from: http://nbuv.gov.ua/UJRN/Sls_2013_10_47[in Ukrainian]

Agamben, 2004 - Agamben G. The Open: Man and Animal. Translated by K. Attell. Stanford: Stanford University Press. 2004 [in English]

Badmington, 2000 - Badmington N. Posthumanism. Palgrave, 2000. 172 p. [in English]

Braidotti, 2013 - Braidotti R. The Posthuman. Cambridge, UK: Polity Press, 2013; 81 [in English]

Ferrando, 2013 - Ferrando F. Posthumanism, Transhumanism, Antihumanism, Metahumanism, and New Materialisms: Differences and Relations. Existenz: An International Journal in Philosophy, Religion, Politics, and the Arts. 2013. Vol. 8. No. 2. P. 26-32 [in English]

Fukuyama, 2002 - Fukuyama F. Our Posthuman Future: Consequences of the Biotechnology Revolution. Farrar, Straus and Giteux /F. Fukuyama. New York: Oxford University Press, 2002. [in English]

Haraway, 1991 - Haraway D. A Manifesto for Cyborgs: Science, Technology, and SocialistFeminism in the Late Twentieth Century. Simians, Cyborgs, and Women: The Reinvention of Nature/ - N/Y/: Routledge, 1991 [in English]

Hassan, 1977 - Hassan I. Prometheus as Performer: Toward a Posthuman Culture? Performance in Postmodern Culture. The Georgia Review. 1977: 830-850. Web. [in English]

Hayles, 2008 - Hayles K. How we become Posthuma: Virtual Bodies in Cybernetics, Literature, and Informatics. University of Chicago Press, 2008, 364 p. [in English]

Polland, 2006 - Polland M. The Omnivore's Dilemma: A Natural History of Four Meals New York: Penguin, 2006, 218 [in English]

Malamud, 2003 - Malamud R. Poetic Animals and Animal Souls. New York: Palgrave Macmillan, 2003 [in English]

Wolfe, 2009 - Wolfe C. What Is Posthumanism? U of Minnesota Press, 2009. 357 p. [in English]

Received: 12 October, 2020 